\title{
The Development of Natural Knowledge Science Learning Module to Improve Student Learning Achievement in Primary School
}

\author{
Sarjana $^{1)}$, Fadillah $^{2)}$, Indri Astuti ${ }^{3)}$ \\ 1)Universitas Tanjungpura, Pontianak, Indonesia \\ E-mail:bapaksarjana@gmail.com \\ ${ }^{2)}$ Universitas Tanjungpura, Pontianak, Indonesia \\ E-mail: fadillahkn@gmail.com \\ ${ }^{3)}$ Universitas Tanjungpura, Pontianak, Indonesia \\ E-mail:indribk91@yahoo.com
}

\begin{abstract}
This study aims to describe (1) the design of the development module for the preservation of living natural resources in the study of natural science; (2) the process of developing modules for the conservation of living natural resources in the learning of natural science; and (3) student learning about the preservation of living natural resources in the learning of Natural Sciences in the fourth grade of SD Negeri 01 Hulu Sungai. This research is descriptive qualitative research to study "the development of learning modules with data collection techniques for interviews, observation, document study. Data analysis techniques ranging from display data, data reduction, data reflection, and conclusions. The results showed that (1) the design of the development module of the preservation of living natural resources material in the learning of Natural Sciences in the form of a front cover with pictures of students studied, preface, table of contents, list of images, concept framework, introduction, instructions for use of modules, competence content, basic competencies, learning activities 1,2,3 and 4, summary, and evaluation, student worksheets, detailed answers, glossary, bibliography, list of life forms; (2) the process of developing modules for the preservation of living natural resources in the learning of Natural Sciences is carried out with the following steps: a). Research and data collection; b). Planning c). Development of learning modules; d). Expert validation; e). Product trial; and (3) all students can achieve their learning achievement in science learning with the development of learning modules with the highest grades of 90 and the lowest scores of 78.
\end{abstract}

Keywords: Development; Modules; Learning; Science; Learning acquisition

\section{INTRODUCTION}

Module is a learning tool that contains material, methods, boundaries, and ways to evaluate that are systematically designed. A competency and sub-competency are packaged in one self-contained module to meet learning needs in certain subjects and certain learning processes. Module material is compiled interestingly to achieve the expected competencies and can be used for self-instructional, and its use is not dependent on other media / selfalone.

An important problem that is often faced by teachers in learning activities is to choose or determine the right learning material or teaching material to help students achieve competence. It is because, in the curriculum or syllabus, instructional material is only written in outline in the form of "subject matter." It is the teacher's job to describe the subject matter so that it becomes a complete teaching material. In addition, how to utilize teaching materials is also a problem. The intended use is how to teach it regarding the teacher, and how to learn it from the student's perspective.

With regard to the selection of this teaching material, in general, the problem in question includes how to determine the type of material, depth, scope, order of presentation, treatment of choosing the source where the teaching material was obtained. There is a tendency for the source of teaching materials to be emphasized in the book. Whereas many sources of teaching materials other than books used for example such as modules, even textbook does not have to be 
one type and do not have to change frequently during this time. Various books can be selected as a source of teaching materials. Including the problem that is often faced by teachers regarding teaching materials is the teacher gives the material or learning material too broad or too little, too deep or too shallow, inappropriate presentation order, and the type of teaching material that is not in accordance with the competencies to be achieved by students. With regard to learning resources often occur every semester change or change the year to replace teaching materials.

In connection with that, it is necessary to formulate election signs and use of teaching materials to assist teachers to be able to choose learning materials or teaching materials and use them appropriately. Signs referred to include the concepts and principles for selecting learning materials, determining the scope, sequence, criteria, and steps for selecting, developing treatment, and the source of learning materials.

The absence of a learning module that is designed so that it can learn by itself to achieve complete goals in accordance with the characteristics of students. Some facts in the field show that problems cause low learning outcomes and student responses because there is no use of modules.

Modules are one of the instructional materials that are arranged systematically with language that is easily understood by students, according to their age and level of knowledge so that they can learn independently with minimal guidance from educators. So that the teaching and learning process is not saturated, and the lessons are very enjoyable. The teaching material that has been compiled systematically and interestingly which includes the contents of the material, methods, and evaluations that can be used independently to achieve the expected competencies and can be a vehicle for students to learn themselves and the natural surroundings, as well as prospects for further development in applying it in everyday life. The learning process emphasizes the provision of direct experience to develop competencies so that students can explore and scientifically understand the natural environment.

The application of natural science (IPA) needs to be done wisely so as not to have a negative impact on the environment. The application of Natural Sciences at the elementary level is expected to emphasize mutual learning (Science, environment, technology, and society) which is directed at the learning experience to design and create work through the application of the science concept and scientific work competency wisely. Learning science needs to be carried out to foster the ability to think, work and be scientific and communicate it as an important aspect of life skills. Therefore, science learning in elementary school emphasizes the provision of direct learning experiences through the use and development of process skills and scientific attitudes. The learning process has been carried out by elementary school teachers in science teaching and learning activities in elementary schools. Students are always faced with factual events in their environment and various kinds of practical or pleasant experiments.

Natural Science Lessons (IPA), is one of the innovative lessons that determines whether or not a student passes. It is in accordance with the UAS implementation instructions (School Final Examination) which sets the standardization of graduation for each subject is 75. Therefore, the quality of this science lesson needs to be improved, because science education in elementary school is the foundation or foundation for mastering science subjects for further education level. Natural science subjects are closely related to the natural environment, directing teachers to use the environment as a learning resource. By utilizing the environment as a source of learning for science, it is expected to help improve the quality of student learning in the learning process.

However, based on the results of observations and interviews at SD Negeri 01 Hulu Sungai, Ketapang Regency shows the fact that around $60 \%$ of teachers have not developed modules as learning resources in natural science subjects. The teacher still uses the lecture method and uses the learning media that has been provided by the school, while the learning resources that are around the school environment are simply ignored.

Module development can support the achievement of science learning objectives and create a student learning atmosphere that requires activeness from students through learning groups as the learning process progresses and the use of the environment as a learning resource. Based on the description, the writer is interested in research with the title "Development of Natural Sciences Learning Module to Improve Student Learning Acquisition in Primary Schools." The focus of this study will be to develop science modules for growing material in the fourth grade of SD Negeri 01 Hulu Sungai.

\section{RESEARCH METHOD}

The research method used in this study is a research development method. What is meant by development research or research and development ( $R$ $\&$ D) is a research method used to produce certain products, and test the effectiveness of these products (Sugiyono, 2016: 407).

According to Darmadi (2011: 6), the main purpose of research and development (Research and Development) is not to formulate or test theories, but to develop effective results to be used in schools or other institutions.

\section{Research Procedure}

This research creates a module product, so the development research model used in developing this learning media is the Borg \& Gall Model. Borg \& Gall in the research model he developed established 
ten procedural steps, (Borg \& Gall 1983: 775), these steps are:

1. Research and information collecting (Research and information gathering)

2. Planning (Planning)

3. Develop preliminary form of product

4. Preliminary field testing,

5. Main product revision (revision of main products)

6. Main testing field (main trial)

7. Operational product revision (Revision of Operational Products)

8. Operational field testing (operational trial)

9. Final product revision (final product revision)

10. Dissemination and implementation (Desimination and Implication)

Development Steps

The steps of this development research are the design steps of the research which will be explained by a chart consisting of three main parts, namely pre-research, initial product development and trial, revision and evaluation. Steps of development research is a combination of the Borg and Gall development research steps and the Research \& Development development model design illustrated in the following chart:

The steps for developing practicum modules consist of three main parts will be explained as follows:

Pre-Research Steps

a. Needs analysis

b. Research and data collection

c. Planning

Draft Product Development

a. Develop Criterion Reference Tests (Develop criteria tests)

b. Instructional Development Strategy (Developing Learning Strategies)

c. Develop and Select Instructional Materials (Develop and choose teaching materials)

d. Design and Conduct of Formative Evaluation media and one expert lecturer in material.

e. Revise Instructional (Revise Learning Package)

The final step of the development design process is to revise the draft environmental-based IPA module. The data obtained based on the results of the formative evaluation are summarized and interpreted to determine the weaknesses of the learning module draft.

Product

The product that has been made will be validated by experts to find out the quality of the product being developed, in this case, the researcher takes three experts, namely: media experts, material experts, and design experts.

\section{RESULT AND DISCUSSION}

1. Design Development of Natural Sciences Learning Module to improve student learning achievement in elementary school.

a. Preliminary research as follows:

Research Findings Results are presented

Table I

Preliminary Research Results

\begin{tabular}{|c|c|}
\hline Aspects analyzed & Findings in the field \\
\hline $\begin{array}{l}\text { Analysis of the curriculum } \\
\text { that applies at school }\end{array}$ & $\begin{array}{l}\text { The curriculum used in Elementary School } 01 \text { Hulu Sungai is } \\
\mathrm{K}-13 \text {. }\end{array}$ \\
\hline $\begin{array}{l}\text { Analysis of the development } \\
\text { of students }\end{array}$ & $\begin{array}{l}\text { 1. Repeat results have not yet reached the KKM where the } \\
\text { KKM Natural Sciences subject is } 75 \text {. while the average } \\
\text { daily replication score is } 65 \text {. } \\
\text { 2. Ability to think less. } \\
\text { 3. Lack of confidence. } \\
\text { 4. Students do not understand what is the teacher said because } \\
\text { only lecture method is not at complete the media. }\end{array}$ \\
\hline $\begin{array}{l}\text { Analysis of the availability of } \\
\text { learning resources. }\end{array}$ & $\begin{array}{l}\text { 1. The book used only handles the teacher. } \\
\text { 2. The library has not functioned. } \\
\text { 3. There is no student handbook }\end{array}$ \\
\hline Analysis of learning tasks & $\begin{array}{l}\text { This analysis is seen when the teaching and learning process } \\
\text { takes place such as: } \\
\text { 1. Study independently of the material in the module. } \\
\text { 2. The concept given by students must be correct. So that } \\
\text { students are able to ask questions if they experience } \\
\text { difficulties in studying modules. } \\
\text { 3. Give a response to how to convey ideas / ideas in conveying } \\
\text { the results of the investigation. }\end{array}$ \\
\hline $\begin{array}{l}\text { Formulate the objectives to be } \\
\text { achieved. }\end{array}$ & $\begin{array}{l}\text { The formulation of the objectives to be achieved is: } \\
\text { 1. Able to explain again the material that has been submitted. } \\
\text { 2. Able to explain the message contained in the module again. } \\
\text { 3. Able to respond to the explanation delivered by the teacher. }\end{array}$ \\
\hline
\end{tabular}

Based on the above table, it can be concluded that in the teaching and learning process at SD 01 Hulu Sungai in the subject matter of Natural Sciences, the material of Wealth Conservation of Natural Resources in Indonesia is not maximized. It causes researchers to be interested in developing a learning module. To find solutions that have been identified. It is why the researcher clarifies the problems faced by the students and hopes that the making of the learning module design is the solution.

b. Planning

Table II

Planning Results

\begin{tabular}{|c|c|}
\hline Planning Aspects & Information \\
\hline $\begin{array}{l}\text { Determine } \\
\text { Learning objectives }\end{array}$ & $\begin{array}{l}\text { 1. The existence of clear learning objectives will } \\
\text { facilitate researchers in making learning activities in } \\
\text { the Natural Sciences learning module. } \\
\text { 2. The goal to be achieved is } \\
\text { a. Able to explain again the material that has been } \\
\text { delivered. } \\
\text { b. Able to explain the message contained in the } \\
\text { module again. } \\
\text { c. Able to respond to the explanation delivered by } \\
\text { the teacher }\end{array}$ \\
\hline Gather learning resources & $\begin{array}{l}\text { Gather learning material from various sources as a } \\
\text { reference in writing Natural Sciences learning modules. }\end{array}$ \\
\hline $\begin{array}{l}\text { Determine the content and order } \\
\text { of subject matter }\end{array}$ & $\begin{array}{l}\text { Determine the content and learning material in the } \\
\text { following ways: } \\
\text { 1. Determine Basic Competencies } \\
\text { 2. Determine indicators of achievement of } \\
\text { competencies } \\
\text { 3. Determine learning objectives } \\
\text { This is done so that the content and sequence of subject } \\
\text { matter will be presented relevant to the learning } \\
\text { objectives that have been formulated previously and in } \\
\text { accordance with the development of elementary school } \\
\text { students. }\end{array}$ \\
\hline Menyusun tes & $\begin{array}{l}\text { Compile a test that refers to the subject matter based on } \\
\text { the learning objectives that have been designed in } \\
\text { advance with the aim to determine the level of mastery } \\
\text { and success of students in understanding the subject } \\
\text { matter contained in the Natural Sciences learning } \\
\text { module. The form of the test made is a multiple choice } \\
\text { of } 20 \text { items, } 10 \text { item description test }\end{array}$ \\
\hline
\end{tabular}

Based on table 4.2 it is concluded that in the design of the learning module with the material for preserving natural resource wealth in 
Indonesia researchers must have good planning so that the module can be used and feasible for students. Planning that is done in determining the learning objectives, collecting learning resources, determining the content and sequence of subject matter, compiling tests to determine the level of mastery and success of the learning modules used in learning Natural Sciences. With this plan, it will make it easier for researchers to do a Natural Sciences learning module planning.

c. The development step of the learning module At this step of development, the initial form of the Natural Sciences learning module produced. This step enters the third step of the $\mathrm{R}$ \& D model, which is Research \& Development, which includes ten steps as stated above, which are effective and efficient. Learning process, and evaluation tools. By paying attention to the purpose of developing a standard product indicator of basic competency, as well as choosing the subject matter, compile a test that is the basis for developing a learning module. The results obtained in the module can effectively improve student learning outcomes in science learning.

\section{d. Expert Validation Step.}

The learning module that has been completed will be validated by experts to find out the quality of the learning module that is being developed before the learning module is tested on students. In this study, three experts are media experts, material experts, and design experts.

2. The Development Process of Material Materials on Conservation of Biological Natural Resources. Development of a module on the preservation of living natural resources in the learning of natural science is carried out with the following steps: Research and data collection step, Planning, Development of learning modules, Expert Validation, and Product Testing. In this process, a small group with good results was tested, medium group trials with good results, and trials of large groups with very good results.

3. Module Development Process material about Preservation of Living Natural Resources.

The development of the module for the preservation of living natural resources in the learning of Natural Sciences is carried out with the following steps:

Research and data collection steps, Planning, learning mode development, expert validation, and product testing. In this process the trial of a small group with good results, a trial of a group with good results, and a trial of a large group with very good results.

4. Learning achievement of students.

Students can achieve the acquisition of learning outcomes in the subjects of Natural Sciences in the preservation of living natural resources with the average results above the KKM in the good category. However, students in using the module are not one hundred percent released need guidance and direction to achieve the goal of independent children.

\section{Table III}

Results of Comments and Suggestions from Students on Learning in Small Group Trials

\begin{tabular}{lll}
\hline \multicolumn{1}{c}{ Rated aspect } & \multicolumn{1}{c}{ Criteria } & \multicolumn{1}{c}{$\begin{array}{c}\text { Student comments / } \\
\text { suggestions }\end{array}$} \\
\hline Presentation & $\begin{array}{l}\text { Presentation of images } \\
\text { needs to be added } \\
\text { interesting. }\end{array}$ & $\begin{array}{l}\text { Presentation of images need } \\
\text { not be added. }\end{array}$ \\
\hline Learning Resources & & $\begin{array}{l}\text { Learning modules have not } \\
\text { fully been able to guide } \\
\text { students to learn material } \\
\text { without teachers. }\end{array}$ \\
\hline
\end{tabular}

Based on Table III above can be concluded that there are still some parts that must be corrected from the learning module including the presentation of the glossary must be added and the learning module cannot fully guide students to learn material without the help of educators. Through small group trials, the researchers made improvements before the students. In the module learning already contained material and indicators about the indicators that they want to achieve.

Medium Group Trial Subjects

The trial subjects consisted of 8 students of grade IV SDN 01 Hulu Sungai, Ketapang district. The group trial process is being carried out on Monday 5th June 2018 at 08.30 - 09.30 WIB. The selection of test subjects is done comprehensively and analyzed as input for researchers in revising the learning module.

Table IV

Results of Comments and Suggestions from

Students on Learning in The Medium Group Trial

\begin{tabular}{lll}
\hline \multicolumn{1}{c}{ Rated aspect } & \multicolumn{1}{c}{ Criteria } & Comments / suggestions \\
\hline Presentation & $\begin{array}{l}\text { Presentation of material in } \\
\text { the learning module can } \\
\text { make learners dig in } \\
\text { information. }\end{array}$ & $\begin{array}{l}\text { Thearning module has } \\
\text { not fully explored } \\
\text { information about the use } \\
\text { of natural resources in } \\
\text { Indonesia. }\end{array}$ \\
\hline
\end{tabular}

Based on Table IV above, it can be concluded that there are still parts of the learning module that must be improved. 
Table V

Results of Students' Comments and Suggestions on Learning in Large Group Trials

\begin{tabular}{|c|c|c|}
\hline & Rated aspect & Criteria \\
\hline A & Use of language & $\begin{array}{l}\text { 1. The language used in the learning module is in } \\
\text { accordance with EYD }\end{array}$ \\
\hline B & Sentence Clarity & $\begin{array}{l}\text { 2. The material presented in the learning module is clear so } \\
\text { that it is easy to understand. } \\
\text { 3. The sentence used in the learning module is clear and } \\
\text { easy to understand. }\end{array}$ \\
\hline $\mathrm{C}$ & Module display & $\begin{array}{l}\text { 4. In an interesting book. } \\
\text { 5. The colors and images in the learning module are } \\
\text { appropriate and interesting }\end{array}$ \\
\hline D & Presentation & $\begin{array}{l}\text { 6. Presentation of material in the learning module can make } \\
\text { students dig up information. } \\
\text { 7. Presentation of glossary / word difficult and foreign is } \\
\text { used according to child level. }\end{array}$ \\
\hline E & $\begin{array}{l}\text { Learning } \\
\text { Resources }\end{array}$ & $\begin{array}{l}\text { 8. The material presented in the learning module can help } \\
\text { students learn independently. } \\
\text { 9. In the learning process there is a student worksheet. } \\
\text { 10. In the learning module there is an answer key, to make it } \\
\text { easier for students to know the extent of their ability to } \\
\text { work on questions or master the material in the module. }\end{array}$ \\
\hline
\end{tabular}

Based on the table above, it can be concluded that students have positive suggestions and comments on the learning module in the utilization of natural resources in their environment. This module media is very relevant to be used to solve problems faced by students in their area.

5. Student learning achievement

From the results of the study, students' cognitive learning acquisition is mostly above KKM. While the affective and psychomotor aspects are obtained through the learning process, including group assignments, observing, classifying, presenting the results of the discussion. The advantages of learning to use this module students can develop interest in reading, develop an attitude of love for the environment by conserving living natural resources.

B. Discussion

1. Design of the module development on the preservation of living natural resources in the learning of Natural Sciences in the fourth grade of SD Negeri 01 Hulu Sungai.

In the design of the module, development requires a good design step so that the process in developing the module can be obtained with maximum results and can be applied in learning in accordance with the learning objectives applied by the environment. The development of this module was carried out using the development steps of Borg and Gall which began with the data collection step. Analysis of the availability of learning resources, analysis of learning assignments, analysis of taught materials, analysis of learning models and methods, formulating objectives, and literature studies on the problems needed by students and solutions provided. After that, enter the step of planning and creating modules. After the module is finished, the module is validated by material experts, media experts, and design experts. After the learning title is declared feasible to be applied in learning, the researcher conducted a trial to the fourth-grade students of SDN 01 Hulu Sungai with a small group of 5 people, a group of 8 and a large group of 30 people.

The procedure for learning the module is developed based on the Dick and Carey design model. The model that uses the application of learning designs that are adjusted according to the steps in sequence. One step from Dick and Carey is the evaluation and revision steps. Each step of this development produces a science learning module.

2. The process of developing the module material on the preservation of living natural resources in the learning of natural science in the fourth grade of SD Negeri 01 Hulu Sungai.

The process of developing modules for the preservation of living natural resources in the learning of natural sciences is carried out with the following steps: a). Research and data collection; b). Planning c). Development of learning modules; d). Expert validation; Material expert, Design Expert, Media Expert. e). Trial product trial one to one three students. Small group trial of 5 students, medium trial of 8 students and a large trial of all students.

3. Student learning acquisition in learning the preservation of living natural resources in learning Natural Sciences in class IV SD Negeri 01 Hulu Sungai.

From the results of the study, the students' learning outcomes can achieve their learning outcomes in natural science learning with the development of learning modules to obtain the average results above the KKM.

\section{CONCLUSIONS}

Based on the focus of the problem, data analysis, and research results and discussion, in general, it can be concluded that the Natural Sciences learning module can improve elementary school students' learning achievement with the following subconclusions:

a. The design of the development module for the preservation of living natural resources in the learning of Natural Sciences is carried out through a model of research \& development where these steps are (1) research and information collecting (Research and information gathering), (2) Planning (Planning), (3 ) Develop preliminary form of product, (4) Preliminary field testing, (5) Main product revision (revision of the main product), (6) Main field testing (main trial), (7) Operational product revision (Revision of operational products), (8) Operational field testing (operational trial).

b. The implementation of learning in the preservation of living natural resources material in the study of Natural Sciences has been prepared with a research step including the conditioning step of students, the preliminary step, the steps of learning activities, evaluation and closing steps. 
c. Learning outcomes on the preservation of living natural resources through the science learning module have increased.

\section{REFERENCES}

Abdullah. Shodiq. 2012. Evaluasi Pembelajaran. Jepara : Pustaka Rizki Putra.

AECT. 2001. Standard for the Accreditation of School Media Specialist and Educational Technology Specialist Programs. Bloomington, in AECT.

Ahmadi. A. 2005. SBM. Metode Belajar Mengajar. Bandung : CV.PustakaSetia. 2010. Strategi pembelajaran Sekolah berstandar Nasional. Surabaya: PT.Prestasi Pustaka Karya.

Anam, Choirul. 2011. Pembelajaran Berbasis Inkuiri (Metode dan Aplikasi). Jakarta: Pustaka Belajar.

Anni, C.T., Rifa'I, A.R.C., Eddy, P., \& Daniel, P. 2006.Psikologi Belajar. Semarang: UPT MKK Unnes.

Arifin, Z. 2009. Evaluasi Pembelajaran Prinsip Teknik dan Prosedur. Bandung: Remaja rosdakarya.

Arikunto, S. 2009. Dasar-Dasar Evaluasi Pendidikan. Jakarta: Bumi Aksara.

2010. Prosedur Penelitian Suatu Pendekatan Praktik. Jakarta: Rineke Cipta.

Darmadi, Hamid. 2011. Metode Penelitian Pendidikan. Bandung: Alfabeta. Eprilia,

Daryanto. 2013. Menyusun Modul.Yogyakarta: Vega Media.

Depdiknas. 2010. Panduan Pengembangan Pembelajaran IPA Terpadu, SMP/MTs. Jakarta: Pusat Kurikulum Balitbang Diknas.

Dick dan Carey. 2005. The Systematic Design Instruction. Boston: Pearson.

Gagne. 2010. Model Desain sistim Pembelajaran. Dian Rakyat.

Hamalik, Oemar. 2008. Kurikulum dan Pembelajaran. Jakarta: Sinar Grafika.

Hamdani. 2011. Strategi Belajar Mengajar. Bandung: Pustaka Setia.

Hartono. 1992. Kiat Mempertahankan Tesis dan Disertasi (Petunjuk Lengkap Tentang Isi dan Proses). Yogyakarta: Garas Communication Yogyakarta.

Hasyim, Adelina. 2016. Metode Penelitian dan Pengembangan di Sekolah. Yogyakata: Media Akademi.

Herawati, Susilo. (2009), Lesson Study Berbasis Sekolah" Guru Konservatif Menuju Guru Inovatif". Malang: Bayumedia Publishing.

Ikbar, Yanuar. 2012. Metode Penelitian Sosial Kualitatif (Panduan Tugas Akhir/karya Ilmiah). Bandung: PT. Refika Aditama.

Imron. Amran. 2006. Modul Pembelajaran yang Efektif dan Menarik. Bandung: PT. Rosdakarya.
Makmun, Samsudin. 2005. Psikologi Kependidikan (Perangkat Sistem Pengajaran Modul). Bandung: Remaja Rosdakarya.

Miarso, Yusufhadi. 2014. Menyemai Benih Teknologi Pendidikan. Jakarta: Kencana.

Muhafid, E.A. dkk. 2013. Pengembangan Modul IPA Terpadu Berpendekatan Keterampilan Proses pada Tema Bunyi di SMP Kelas VIII. Unnes Science Education Journal. 2(1): 140-148.

Muljono, P. 2007. Kegiatan Penilaian Buku Teks Pelajaran Pendidikan Dasar dan Menengah. Buletin BSNP.11(1): 1-24

Mulyasa. 2006. Kurikulum Tingkat Stuan Pendidikan Suatu Panduan Praktis. Bandung: Remaja Rosdakarya.

Ningsih, Sekar. 2015. Buku Pintar Pohon Ulin. Jakarta: Study Book

Parmin, E. Peniati. 2012. Pengembangan Modul Mata Kuliah Strategi Belajar Mengajar IPA Berbasis Hasil Penelitian Pembelajaran. Semarang. Jurnal Pendidikan IPA Indonesia/ JPII 1 (1) (2012) 8-12.

Prastowo, A. 2011. Panduan Kreatif Membuat Bahan Ajar Inovatif. Yogyakarta: Diva Press.

Pribadi, Benny A. 2011. Model Desain Sistem Pembelajaran. Jakarta: Dian Rakyat

Purwanto, Rahardi, \& Lasmono. 2007. Pengembangan Modul. Jakarta:Depdiknas.

Regelud, Charles M. 1999 Insructional Design Theories and Models Volume: New Jersey: Lawrence Erlbaum Asociates Syracause University.

Samatowa, Usman. (2006). Bagaimana Membelajarkan IPA di Sekolah Dasar. Jakarta: Direktorat Pendidikan Nasional.

Sardiman. A.M. 2004. Interaksi dan Motivasi Belajar Mengajar. Jakarta: PT RajaGrafindo.

Sugiyono. 2010. Metode Penelitian Kuantitatif, Kualitatif, dan R\&D. Bandung: Alfabeta.

Sukmadinata, Nana. 2005, Landasan Psikologi Proses Pendidikan,. Bandung: PT Rosda Karya.

Trianto. 2007. Model-model Pembelajaran Inovatif Berorientasi Konstruktivistik. Jakarta: Prestasi Pustaka.

Tim TPK BPPTKPK. Teknik Penyusunan Modul. Bandung: Dinas Pendidikan Provinsi Jawa Barat.

Vanides, J., Yin, Y., Tomita, M., \& Ruiz-Primo, M.A. 2005. Using Concept Maps in the Science Classroom. Science Scope, 28(8): 27-31. 